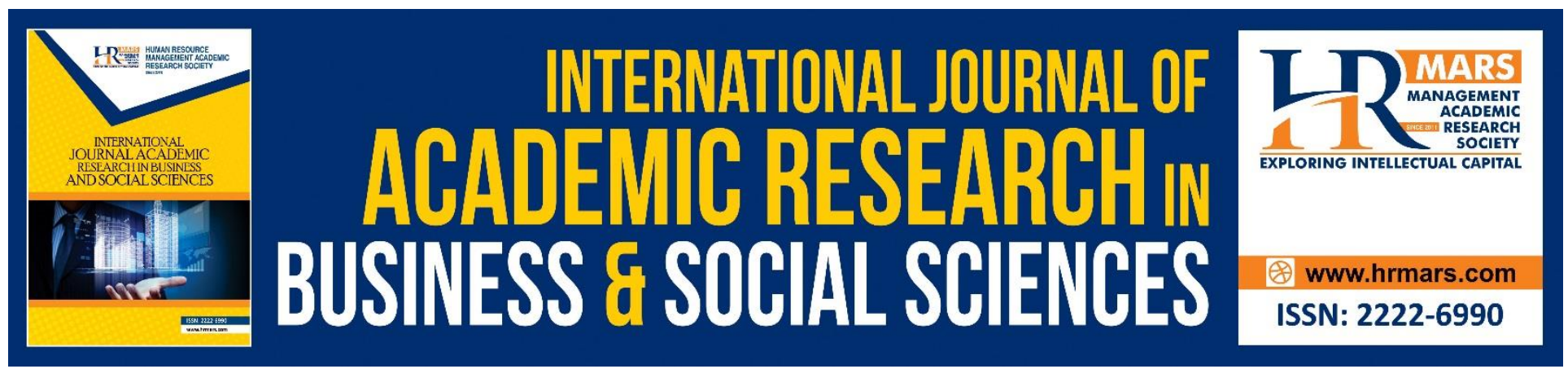

\title{
Sexuality and Sources of Information: A Study of Unwed Teenage Mother's in Women's Shelter in Malaysia
}

\author{
Zakiyah Jamaluddin, Abdul Razak Abd Manaf, Rusimah Sayuti, \\ Rajwani Md Zain \& Noor Azizah Ahmad
}

To Link this Article: http://dx.doi.org/10.6007/IJARBSS/v8-i11/4885

DOI: 10.6007/IJARBSS/v8-i11/4885

Received: 29 Sept 2018, Revised: 23 Oct 2018, Accepted: 06 Nov 2018

Published Online: 23 Nov 2018

In-Text Citation: (Jamaluddin, Manaf, Sayuti, Zain, \& Ahmad, 2018)

To Cite this Article: Jamaluddin, Z., Manaf, A. R. A., Sayuti, R., Zain, R. M., \& Ahmad, N. A. (2018). Sexuality and Sources of Information: A Study of Unwed Teenage Mother's in Women's Shelter in Malaysia. International Journal of Academic Research in Business and Social Sciences, 8(11), 67-75.

Copyright: (C) 2018 The Author(s)

Published by Human Resource Management Academic Research Society (www.hrmars.com)

This article is published under the Creative Commons Attribution (CC BY 4.0) license. Anyone may reproduce, distribute, translate and create derivative works of this article (for both commercial and non-commercial purposes), subject to full attribution to the original publication and authors. The full terms of this license may be seen

at: http://creativecommons.org/licences/by/4.0/legalcode

Vol. 8, No. 11, 2018, Pg. 67 - 75

http://hrmars.com/index.php/pages/detail/IJARBSS

JOURNAL HOMEPAGE

Full Terms \& Conditions of access and use can be found at http://hrmars.com/index.php/pages/detail/publication-ethics 


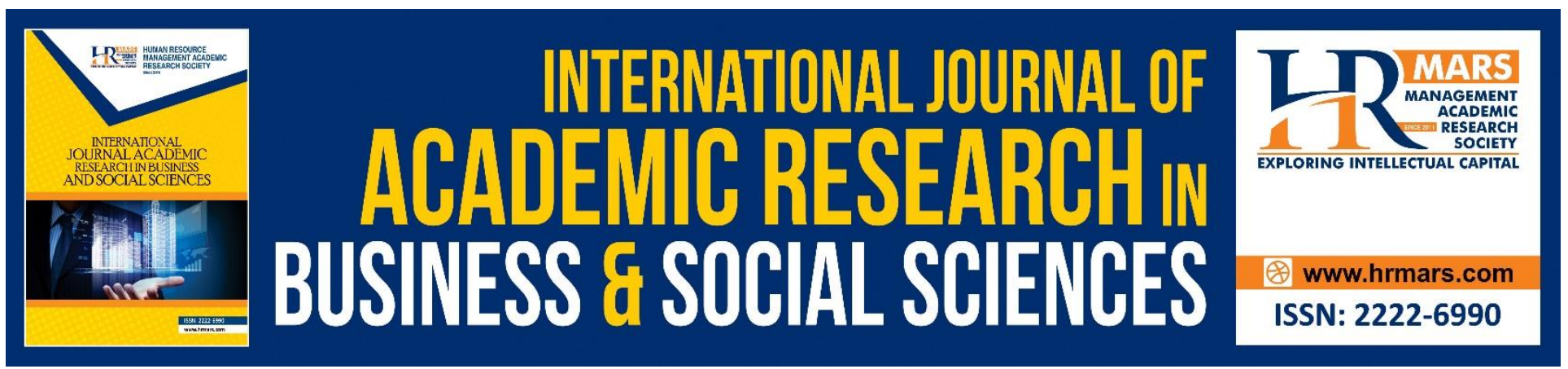

\title{
Sexuality and Sources of Information : A Study of Unwed Teenage Mother's in Women's Shelter in Malaysia
}

\author{
Zakiyah Jamaluddin ${ }^{1}$, Abdul Razak Abd Manaf', Rusimah Sayuti ${ }^{3}$, \\ Rajwani Md Zain ${ }^{4} \&$ Noor Azizah Ahmad ${ }^{5}$ \\ Social Work Program, School of Applied Psychology, Social work \& Policy, Universiti Utara Malaysia \\ Sintok Kedah, Malaysia \\ Email: zakiyah@uum.edu.my
}

\begin{abstract}
The issue of unmarried teen pregnancies is often calls the subject of attention of various parties. Statistics from the relevant authorities namely the Welfare Department of Malaysia and those of the National Registry Department of Malaysia point to the steady annual increase in the number of unmarried teen pregnancies. This study looks at the aspects of the sources whereby information on sexuality are obtained by unmarried teens at one of the women's shelter in Malaysia. Results showed that a number of sources the respondents often resort to, for sexual information among the favoured choices are information's gained from friends, boy/girlfriends, compact disc (cd), video compact disk (vcd), the internet and books/magazines. Parents however, are those least consulted on the aspects of sexuality. It follows that parental monitoring is required to ensure that teenage would not get the wrong information's on sexuality.
\end{abstract}

Keywords: Sexuality, Sources Of Information, Teenagers, Unmarried Mothers, Women's Shelter

\section{Introduction}

Sexuality encompasses the aspects of trustworthiness, action, behaviour, lust, relationship and identity (Bywater \& Jones, 2007).The issues in sexual development features highly in the mix of problems in teenagers' life. Sexual development affects the biological, social and psychological makeup of teenagers. Physical or biological development of children and adolescents, sexual and physiological brings about psychological issues such as emotions, stress, worry, shyness, and so forth. This situation would affect the social aspects adversely where without the required knowledge and information would likely to lead to behaviours that society would find unacceptable. The word sexuality which is a derivedfrom the word sex is also often refers to matters pertaining to sex, chiefly, 
INTERNATIONAL JOURNAL OF ACADEMIC RESEARCH IN BUSINESS AND SOCIAL SCIENCES Vol. 8, No. 11, Nov, 2018, E-ISSN: 2222-6990 (C) 2018 HRMARS

sexual differences and sexual activity. It is also expressive of manhood or womanhood, covering aspectssuch as feelings, thoughts, attitudes, beliefs, values and behaviours (Hasan, 2009).

The sources of information on sexuality accepted by teenagers are of key importance, as this affect the validity of the information. Individuals who are in the early teens usually have limited sources of information such as friends and the internet. However, this information is often times inaccurate (Eggleston, Jackson and Hardee, 1999). Their sources of reference and information on the issues of sexuality can determine the individuals' level of knowledge and attitudes towards sexual activities. Malek et al. (2010) and Amazigo et al. (1997) are given to find usual sources of information resorted to by students for sexual information, namely 1) peers, 2) books, magazines and photographs, 3) audiovisual (CD, films, etc.), 4) school, 5) counselling centre, 6 ) family (parents or siblings) and 7) close family member. While Duyan and Duyan (2009) found that two main sources to obtain information on HIV / AIDS and other sexually transmitted diseases are medical staffs (including doctors and nurses) and peers.

Morris, Young and Jones (2000) found the important roles of family and peers (friends) in influencing and directing the sexual behaviour among school children. Guidance and motivation given by parents and other family members at home have a tendency to keep their virtue chastity and a more conservative attitude towards sexual activity. They would deliberately abstain to preserve their virtue (virgin status). Conversely teenagers who look on to peers as source of information on sexuality have a high tendency to premarital sexual relationship. It seems clear therefore that parental guidanceas a source of information on sexuality for their children is very relevant.

UNFPA Report (2000) has indicated that teenagers find information on sexuality from various sources. It insisted the messages should be general in nature to prevent undesired behaviours. Teenagers claim the presentation of sexual representation risk are vague and unclear. Further, the messages are negatively potrayal, uninteresting and tend to instill fear.

Open sex activities among Malaysia teens are on the whole a cause of great concern. Reports abound on the prevalency of the activities in their own neighbourhood with the impunity of any parental awareness. Parents are the main educators in any efforts to keep teenager off these immoral activities (Deptula, Henry \&Schoeny, 2010). A study by Miller et al. (2001) reported that the teenage pregnancy was closely related to parental relationship. Activities under close parental guidance and supervision help teenagers to stay clear of unwanted pregnancies. Values held by the parent contribute to the development of teenager in a healthy social environment.

A study by Siti Salwani (2009) found that the wrongful sexual actsof 105 respondents out of a total of 124 respondents wereinfluenced by pornography. Driven by curiosity, forced under the basis of love to their partners, various lewd materials and so forth, draw teenagers into wrongful sexual acts.

Bleakley, Hennesy, Fishbin\& Jordon (2009) study on sources of sexual information among 459 youth aged between 14-16 years. Their study found that the most frequently reported sources were friends, 
INTERNATIONAL JOURNAL OF ACADEMIC RESEARCH IN BUSINESS AND SOCIAL SCIENCES Vol. 8, No. 11, Nov, 2018, E-ISSN: 2222-6990 (C) 2018 HRMARS

teachers, mothers, and media. Regression analyses indicated that learning about sex from parents, grandparents, and religious leaders was associated with beliefs likely to delay sex; friends, cousins, and media were associated with beliefs that increase the likelihood of having sexual intercourse.

Meanwhile Tanton et al. (2015) found that school lessons are the main source of information about sex, compared to other sources like families. This study was done in meeting young people's sex education needs in Britain by examining the current situation and changes over the past 20 years (1990-2012) in sources of information. This finding supported that there's a need to improved sex and relationships education in schools alongside greater involvement of parents and health professionals.

Teenagers exposed to media with sexual contents are reported to have greater intention towards sexual relationships and other forms of sexual activities. L'Engle, Brown and Kenneavy (2006) described the mass media as an important dimension for young people as well as directing their sexual behavior. Teenager utilises mass media use to fantasized sex and obtain information they need. The information gained are for entertainment and not for guidanceor lesson.

Study by Gonzalez-Ortega et al. (2015) found that many adolescents learn about sex online. A total of 3809 secondary students aged between 12 to 17 years, completed a written survey anonymously. Results showed $68.4 \%$ of the participants had received sexual information online. Based on this findings, professionals are encouraged to incorporate internet-based approaches into their sexual education interventions with this age group.

The need arise to balance information from the medias and those from teachers and parents as unfiltered media information hazards danger. Then only would sexual relationship from sexual education on sexual and reproductive health be promoted (Azriani et al. , 2011). It should be noted that the validity of information from the mass media especially the Internet can be doubtful.Hence this study lends itself to ascertain the source of information referred by teenagersin matters on sexuality.

\section{Methodology}

This study uses a quantitative research design method, using cross-sectional survey method by using questionnaire. A women's shelter in Peninsular Malaysia was chosen for the data collection of this study. There were 119 respondents in the institutions, and 99 respondents were selected as research sample using purposive sampling technique. The questionnaires were distributed to existing respondents and those who avail themselvesfor this study.

Study questions on sources of sexual information were designed and modified from previous studies (Amazigo et al., 1997; Azlin Hilma Hillaluddin et al., 2004; Kirby, 1988; Malek et al., 2010; Raudah Abu Hassan, 2003; Task Group and Research on HIV / AIDS , USM , 2010; UNFPA report, 2000) . Data were analyzed using SPSS (Statistical Package for Social Science) version 16. The information and data were analyzed using descriptive statistical analysis including percentage, cross tab, and mean. 
INTERNATIONAL JOURNAL OF ACADEMIC RESEARCH IN BUSINESS AND SOCIAL SCIENCES

Vol. 8, No. 11, Nov, 2018, E-ISSN: 2222-6990 @ 2018 HRMARS

\section{Results and Discussion}

Respondent's Demography

In this study, a total of 97 respondents are single and one have been divorced / separated. The majority (94 respondents) are Muslims and five people are Hindus. The acquired average age of respondents was 16 years. Basis of admittance to the shelter being 54 respondents were uncontrolled, 18 respondents due to pregnancy, 15 respondents were runaways and four respondents were raped victims. Eight respondents did not specify the reason for entry. In terms of educational status, a total of 44 respondents are still schooling, and 55 respondents were not in school.

\section{Respondents Family Profile}

The majority of respondents are still living with their biological mother ( 81 respondents) and father (65 respondents). The respondents living with stepmother or stepfather are six and nine respectively. There arealso respondents living with a foster mother or foster father being four respondents and five respondents respectively. The highest level of education for respondent's mother and father is Sijil Pelajaran Malaysia (SPM- Malaysian Education Certificate) counting at 33 and 30 respectively. Marriedstatus has the highest numbers among the mothers and fathers of the respondents standing at 72 and 68 respectively. Most of the respondent's mothers are not in employment / full-time housewives / pensioners (34 people), while the father of the respondents have the highest number for being in employment in the factories, industries and construction sectors, (18 people).

\section{Sources of Sexual Information}

The respondent's sources of information in sexual matters were from friends, books, boyfriends, magazines and other sources. The highest numbers for the sources of sexual information were from friends (88) and boyfriends /girlfriends (84). This is due to the respondents spending most with friends and boyfriends /girlfriends, same age and the strong influence they have among themselves. Respondents also got the internet and from the compact disc (cd) and video compact disc (vcd). The respondents stated that they did not get much information on sexual matters from the religious classes and form their parents (see Figure 1). 
INTERNATIONAL JOURNAL OF ACADEMIC RESEARCH IN BUSINESS AND SOCIAL SCIENCES

Vol. 8, No. 11, Nov, 2018, E-ISSN: 2222-6990 @ 2018 HRMARS

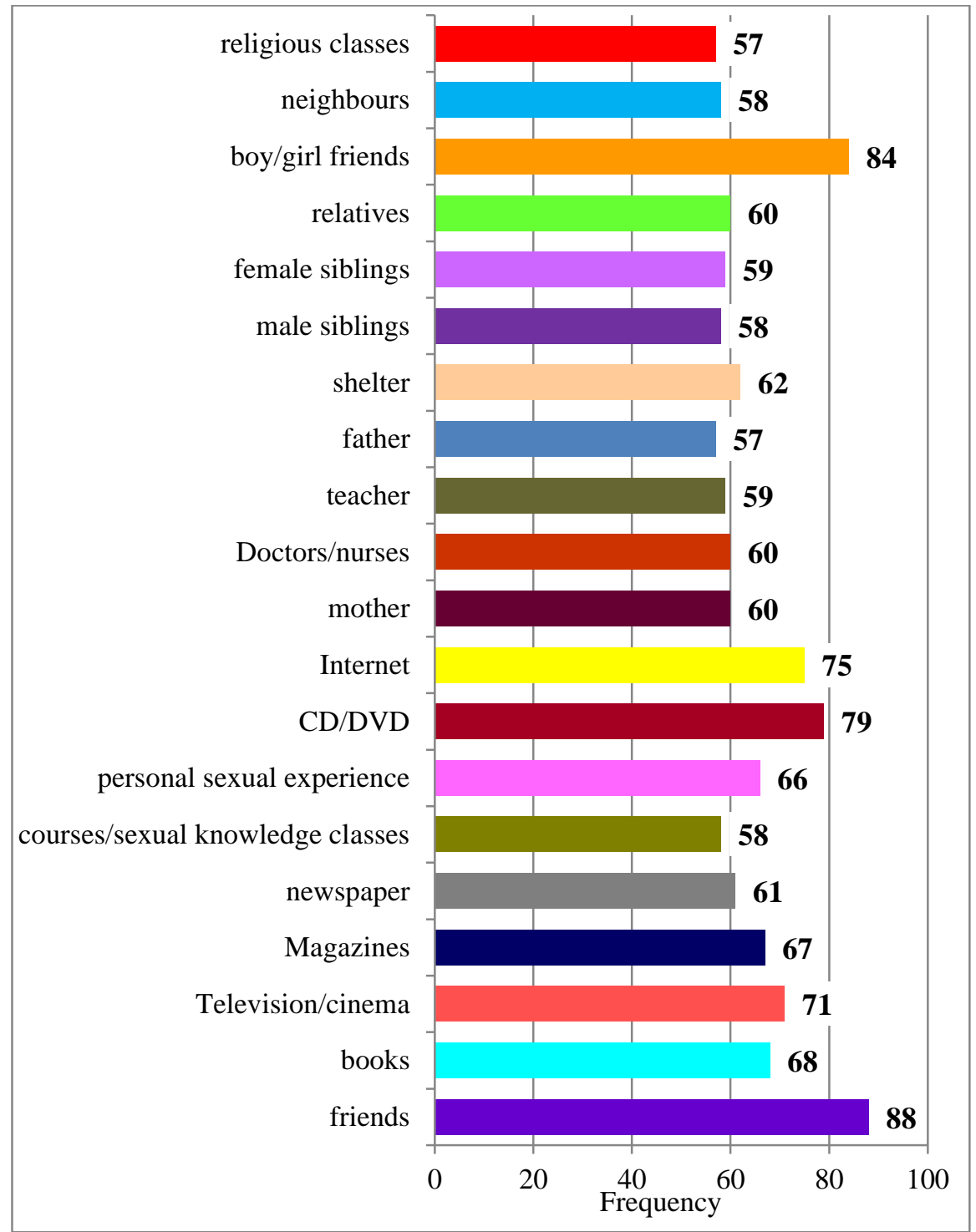

Figure 1 Sources of sexual information by the respondents

The findings indicate that there are several sources of sexual information that is often referred by the respondent. The most frequently used sources are from friends, boy/girlfriends, cd, vcd, internet, television / movies, books / magazines and also through personal sexual experiences.Based on the study, it transpired that family are the least source respondents go to or refer to for sexually related information.

This study found that friends, boy/girlfriends, cd, vcd, and the internet are the main sources of sexual information and this is in line with previous studies (Azriani et al. (2011); Bleakley, Hennesy, Fishbin\& Jordon (2009); Kaiser et al. (2003); L'Engle, Brown and Kenneavy (2006); Gonzalez-Ortega et al. (2015). 
INTERNATIONAL JOURNAL OF ACADEMIC RESEARCH IN BUSINESS AND SOCIAL SCIENCES Vol. 8, No. 11, Nov, 2018, E-ISSN: 2222-6990 C 2018 HRMARS

According to Azriani et al. (2011) the main source of sexual information is from friends (64.4\%). The lack of information of important aspects of sexuality and reproductive health shows a need factor to strengthen sexual education and reproductive health education. Whereas according to Kaiser et al. (2003) friends are the usual source for sexual and reproductive health and the same source also as in other researcher's findings.

Source of information relating to sexuality as accepted by teenagers is important for the validity of the particular information. Individuals at the early teen stage are usually of limited means of sources to friends and the Internet, but the information available are not necessarily accurate (Eggleston et al., 1999).

Siti Salwani study (2009) found that sexual misconduct made by 105 respondents out of 124 respondents was due to pornography. Curiosity, compulsion of love towards the partner, pornography and so forth, drives the teenagersto be involved in activities encouraging sexual misconduct.

Adolescents exposed to media containing sexual content are more intent to engage in sexual intercourse and other sexual activities. L'Engle et al. (2006) stated that the mass media is one of the important dimensions for teenagers and also affects the sexual behavior. Most of the mass media use by youth in relation to sexual fantasies and get the information they need. Such information is more for entertainment purposes but not as a guide and lessons.

However, fewer respondents referring to teachers and schools for sources of sexual information and this is not in line with study by Tanton et al. (2015) which found that school lessons are the main source of information about sex, compared to other sources like families.

\section{Conclusion}

Family, friends and the media play an important role in the issue of teenage pregnancy out of wedlock. Thus the family needs to forge closer relationships with their children and share their problems and monitor the behavior of their children. This is due to the facts that peer have strong influence on the teenagers behaviour. At the same time the explosion of information technology cannot be curbed in line with globalisation. However, families should monitor the activities of their children and provide adequate information to prevent children find the wrong information.

This study is significant in contributing to the national policy. The lack of appropriate sources of information regarding the important aspects of sexuality and reproductive health shows a need to strengthen sexual and reproductive health in school.

\section{Acknowledgement}

The authors wish to thank the Ministry of Higher Education Malaysia in funding this study under the Research Acculturation Grant Scheme (RAGS) S/O code 12719, and Research and Innovation Management Centre, Universiti Utara Malaysia, Kedah for the administration of this study. 
INTERNATIONAL JOURNAL OF ACADEMIC RESEARCH IN BUSINESS AND SOCIAL SCIENCES

Vol. 8, No. 11, Nov, 2018, E-ISSN: 2222-6990 @ 2018 HRMARS

\section{References}

Amazigo, U., Silva, N., Kaufman, J., \&Obikeze, D. N. (1997). Sexual activity and contraceptive knowledge and use among in-school adolescents in Nigeria. International Family Planning Perspective, 23(1), 28-33.

Amir Hasan Dawi (2009). Pendidikan seks suatu perspektif sosial. Tanjong Malim: Penerbit Universiti Pendidikan Sultan Idris.

Azlin Hilma Hillaluddin, Yusmarhaini Yusof \& Chan Cheong Chong. (2004). Pengetahuan kanak-kanak sekolah rendah mengenai penganiayaan seksual : Satu kajian penerokaan. (Research report). Universiti Utara Malaysia.

Azriani Ab Rahman, Razlina Ab Rahman, Mohd Ismail Ibrahim, Halim Salleh, Shaiful Bahri Ismail, Siti Hawa Ali, Wan Manan Wan Muda, Maizun Ishak \& Amaluddin Ahmad. (2011). Knowledge of sexual and reproductive health among adolescents attending school in Kelantan, Malaysia. Southeast Asian Journal of Tropical Medicine and Public Health, 42(3), 717-725.

Bleakley, A., Hennesy, M., Fishbin, M. \& Jordon, A. (2009).How Sources of Sexual Information Relate to Adolescents' Beliefs about Sex. Am J Health Behav, 33(1), 37-48.

Bywater, J., \& Jones, R. (2007).Sexuality and social work. Exeter: Learning Matters Ltd.

Deptula, D. P., Henry, D. B., \&Schoeny, M. E. (2010). How can parents make a difference? Longitudinal associations with adolescent sexual behavior.Journal of Family Psychology, 24(6), 731-739. doi: $10.1037 / \mathrm{a} 0021760$.

Duyan V.,\&Duyan G. (2009). HIV/AIDS knowledge among a group of youngsters under social protection in Turkey.Turk J Med Sci 2009, 39(3), 429-437.

Eggleston, E., Jackson, J., \& Hardee, K. (1999).Sexual attitudes and behaviour among young adolescents in Jamaica.International Family Planning Perspectives, 25(2), 78-84.

Gonzalez-Ortega, E., Vicario-Molina, I., Martinez, J.L. \&Orgaz, B. (2015).The Internet as a Source of Sexual Information in a Sample of Spanish Adolescents: Associations with Sexual Behavior, Sexuality Research and Social Policy, 10.1007/s13178-015-0196-7

Kaiser, H. J., Hoff, T., Green, L., \& Davis, J. (2003).National survey of adolescent and young adults: Sexual health knowledge, attitudes and experiences. Menlo Pork, CA: Henry J. Kaiser Family Foundation.

Kirby, D., Barth, R. P., Leland, N., \&Fetro, J. V. (1991).Reducing the risk: Impact of a new curriculum on sexual risk-taking. Family Planning Perspectives, 23, 253-262.

Kumpulan Bertindak dan Penyelidikan HIV/AIDS (AARG), USM (2010).Pengetahuan dan sikap pelajar IPT terhadap HIV/AIDS. Universiti Sains Malaysia: Research Report.

L'Engle, K. L., Brown, J. D., \&Kenneavy, K. (2006). The mass media are an important context for adolescent sexual behavior. Journal of Adolescent Health, 38, 186-192. doi:10.1016/j.jadohealth.2005.03.020.

Malek, A., Abbasi Shokoohi, H., Faghihi, A. N., Bina, M., \& Shafiee-Kandjani, A. R. (2010). A study on the sources of sexual knowledge acquisition among High School Students in Northwest Iran. Archives of Iranian Medicine,13(6), 537-542.

Miller, B. C., Benson, B., \& Galbraith, K. A. (2001). Family relationships and adolescent pregnancy risk: A research synthesis. Developmental Review, 21, (1-38). doi:10.1006/drev.2000.0513. 
Morris, J., Young, M., \& Jones, C. (2000). Self-esteem and adolescent sexual behavior among students at an Elite Bolivian School. The International Electronic Journal of Health Education, 3(1), 3643.

Raudah Abu Hassan. (2003). Pengetahuan seks di kalangan pelajar Sekolah Menengah Kebangsaan Changlun. Academic Exercise: Universiti Utara Malaysia.

Report of the UNFPA Intercountry Workshop Adolescent Reproductive Health for East and SouthEast Asia and the Pasific Island Countries. (2000). Bangkok: United Nations Population Fund.

Siti Salwani Azmi. (2009). Persepsi terhadap tingkah laku seks sebelum nikah di kalangan mahasiswa Melayu, Academic Exercise, Universiti Malaya, Kuala Lumpur.

Tanton, C., Jones, K.G., MacDowall, W., Clifton, S., Mitchell, K.R., Datta, J., Lewis, R., Field, N., Sonnenberg, P., Stevens, A., Wellings, K. Johnson, A.M., Mercer, C.H. (2015). Patterns and trends in sources of information about sex among young people in Britain: evidence from three National Surveys of Sexual Attitudes and Lifestyles. Sexual Health Research, BMJ Open, 1-11. doi: 10.1136/bmjopen-2015-007834. 